\title{
Contribution of Muslim Physicians and Scholars of Spain During the period between the ninth and thirteenth Centuries
}

\author{
M. Basheer Ahmad, M.D., F.R.C. Psy. (Lond), F.R.C.P. (C), F.A.P.A.
}

Dallas, Texas

DOI: http://dx.doi.org/10.5915/23-2-15083

\begin{abstract}
The period of the 9 th to 13 th centuries is regarded as a golden period of Muslim history during which Muslims had established the most powerful empire and had produced the most brilliant physicians, scientists and scholars. These scholars made their original contributions and significant additions to existing scientific knowledge. In Cordoba ("Qurtubah") and other cities of Spain, Muslim scholars established some of the most renowned universities where European scholars came to learn. Muslim scholars achieved excellence in all sciences, including but not limited to, mathematics, astronomy, philosophy, chemistry and medicine. They established general hospitals with speciality units, defined criteria for admission to medical schools and described characteristics of a competent physician. Christian scholars subsequently translated the most valuable material from Arabic to Latin and these books served as standard textbooks in European universities for several centuries. The Muslim contributions became the basis of culture, scientific and technological achievement which has had a lasting influence on the world. I do hope that the knowledge of the work done by the Muslim scholars during the 9 th to 13 th centuries period will serve as a source of inspiration to current and future Muslim generations.
\end{abstract}

Key words: Muslim physicians, Muslim scholars, 9th-13th centuries, Muslim Spain.

One of the golden periods of Muslim history was betwen the 8 th and 15 th century when Muslims ruled Spain and contributed a great deal to the enhancement of scientific knowledge and civilization.

In the year 711 A.D. a young Muslim soldier named Täriq ibn Ziyâd landed in Spain with 12,000 soldiers and within one year the whole of Spain was

From the Department of Psychiatry

South Western Medical School

Dallas, $T X$

Presented at the IMA 23rd Annual Convention Nerja, Spain, June 1990

Reprint Requests: M. Basheer Ahmed, M.D.

43 Bounty Road West

Fort Worth, Texas 76132 conquered. ${ }^{1}$ Muslims ruled Spain for about the next 800 years. Muslim Spain rose to its height of glory during the reign of 'Abdul Rahmān III from 912 961 A.D. Cordoba ("Qurtubah") was the capital of Muslim Spain and was perhaps the most flourishing city in the world. Qurtubah had a population of half a million, with 700 mosques, 40 hospitals and 80 libraries which contained 500,000 manuscripts. ${ }^{2}$ This was the largest collection of books in the then known world and included works of great Greek and Muslim scholars. Qurțubah's famous mosque has inspired the Muslim scholars even in the modern ages. Iqbal's famous poem "Masjid Qurtubah" was a source of inspiration to thousands of Muslims. It was from Muslim Spain that the modern civilization spread over the whole of Europe. European scholars came to Spanish universities and returned home with teachings of Muslim scholars. Muslims can rightfully 
claim the distinction of having introduced civilization, culture and enlightenment to Europe of the dark ages. Muslim Spain with its renowned universities of Cordoba, Seville and Valencia was the most important center of learning in the world during the middle ages.

Islam, with its tolerance and encouragement of both secular and religious learning, created the necessary climate for free exchange and propagation of ideas and knowledge. Arabic became the international language of science in a short period. ${ }^{3}$

When the rest of Europe was struggling to come out of the darknes of illiteracy, Muslim Spain was the center of a civilization which illuminated the whole world with the light of its brilliance. "The world is held up by four pillars; the wisdom of the learned, the justice of the great, the prayers of the righteous and the valor of the brave" was the inscription most often found above the entrances of the universities in Spain during the Muslim era. ${ }^{4}$ The list of the Spanish Muslim scholars of science and philosophy, which contributed to the enhancement of the world's knowledge, is very long. Few names stand out from among these.

'Abul Qasim al-Zahrâwì (936-1035 A.D.) also known as AlbuCasis in the West, was an eminent 10 th century surgeon in Spain. He was the court physician to Caliph al-Hakam II (961-976 A.D.). He was very skilled in the use of simple and compound remedies and thus he was also known as the "Pharmacist Surgeon". He wrote an encyclopedia of medicine and surgery entitled "al-Tașrif li-man 'ajaza 'an al-Ta'lif"' This encyclopedic work contains 30 treatises dealing with anatomy, physiology, dietetics, medicine and surgery. Al-Zahräwi had a sound knowledge and understanding of the relevance of anatomy in surgical procedures. He stated that the art of medicine is lengthy and one should practice anatomy before entering in surgery (referred by alZahrawi as a "hand operation"). The first two treatises were mainly devoted to human anatomy. The last three treatises were primarily devoted to surgery. The first dealt with cautery, which was used extensively in Arabia and it contained a detailed description of the use of various instruments. There was also an extensive description of incisions, perforation, wounds and the healing of wounds. The second book was devoted mostly to lithotripsy, lithotomy, fractures, dislocations and special treatment of fractures of the pelvis. The third book described detailed procedures of ophthalmic (cataract) operations and dental surgery. One hundred and five chapters were devoted to describing the details of various operative procedures including amputation and the crushing of bladder stones. He used the grooved probe for dislodging urethral obstructions and invented a sponge tipped probe for dislodging foreign particles from the gullet. He also used a syringe for the irrigation of the bladder and the cleaning of the ear. In addition, al-Zahrâwi wrote about obstetrics describing instruments used for delivery. His books contain the pictures of gynecological instruments used in the 10th century, e.g. vaginal speculum and instruments to perform craniotomy for delivering the dead fetus. Al-Zahräwi also treated hydrocephalus in young children by making a small hole in the skull by means of cauterization to extract the fluid. His last treatise contained a description of 200 surgical instruments. The majority of these instruments were devised, designed and used by al-Zahrāwi himself., ${ }^{3,5,6}$

His celebrated writings were translated into Latin by Gerard of Cremona in 1187 A.D. and were used as the standard textbook of medicine in Europe for several centuries. His writings on anatomy and surgery raised the author to the level of Hippocrates and Galen. In fact, his work represented the first step of surgery as an independent specialty away from medicine, grounded on the knowledge of anatomy. "Al-Tasrif" became famous in the universities of Europe in the Middle Ages and was the chief reference work for surgery in the universities of Italy and France.'

Al-Zahrāwi was the first to establish a large medical school in Muslim Spain. He was very meticulous about maintaining a high standard of education and medical ethics. He encouraged discipline and a positive attitude. Al-Zahräwi was against the use of alcoholic beverages in therapy. He discussed problems related to alcohol addiction and some of the consequences resulting from chronic alcohol use e.g. melancholia, convulsions, heart attacks and cirrhosis of the liver. Al-Zahrāwi wrote extensively about child rearing, discipline and the responsibility of teachers and parents. "Al-Tasrif", also contained a description about discipline and temperament. He advocated compassion as well as chastisement when his students lied or cheated. $\mathrm{He}$ described the conventional code of behavior in adolescents, and emphasized that students should be instructed about the way they speak, sit, eat and drink, and relate to others. Al-Zahrawi was one of the first scholars in Islam to promote the nursing profession, and encouraged women to become midwives. Because of his enthusiasm and devotion, good hospitals and nursing care was enhanced in Andalusia."

Ibn Hazm (994-1064 A.D.) was one of the intellectual giants of Muslim Spain. He was a scholar and a prolific writer, having written 80,000 pages in four hundred volumes on various subjects including Islamic theology, history, philosophy, science and medicine. He was born and grew up during the glorious period of Muslim Spain, but he had also seen the political divisions and internal wars which subsequently resulted in the decline of Muslim power 
there. He took a leadership role in reforming the social, political, scientific and religious institutions to prevent them from decline. He was convinced that all worldly things including sciences were subordinate to Islam. His thorough knowledge of the Qur'an and Hadith (Prophet Muhammad [PBUH] sayings) made him an expert on Muslim jurisprudence. He, like many other scholars of that time faced strong opposition, and restrictions were imposed upon him. However, his ideas survived and influenced many succeeding generations. His most famous work is "Marätib-ul-'ulüm" (the categories of the sciences), which discussed the importance of true research based on observation and inference not just on philosophical or hypothetical ideas. He also emphasized the harmonization and interdependence of the religious and secular sciences. He emphasized the pursuit and study of as many sciences as possible within the ability of the individual. Ibn Hazm wrote extensively on the subject of medicine. He divided the science of medicine into two parts: the science of the soul, which is the result of science of logic and deals with moral conduct and behavior, and the science of the body, which consists of the knowledge of the nature of the body and of illness, its causes and responses to diet and drugs. He described the medicine of the body in two parts; a) surgery dealing with cauterization, amputation, etc. and b) knowledge of drugs. He further divided illness into two parts; preservation of health by preventing the occurrence of diseases and the treatment of diseases when they occur. Ibn Hazm also wrote about what is expected of a good doctor. "A doctor should be kind, understanding, friendly, good and able to endure insults and criticism. He must keep his hair short, his finger nails clean, he must wear white clean clothes and behave with dignity".

Even until the Renaissance, Christian scholars tended to confound astronomy with astrology and chemistry with alchemy. Ibn Hazm was outspoken on this point. He was a staunch antagonist to people who supported the ideas of talisman, magic, alchemy and astrology. He described astrology and alchemy as pseudosciences which were unproven, false and forged subjects. Andalusian scholars also had to deal with theological problems posed by the introduction of Greek philosophy into a context of Islam. How could reason be reconciled with revelation? Ibn Hazm was one of the first to deal with this problem. $\mathrm{He}$ had no difficulty in relating logic to Islam. He gave illustrative examples of how it could be used in solving legal problems drawn from the "Shari'ah" (Islamic Jurisprudence). Nothing illustrates the ability of Islam to assimilate foreign ideas better than Ibn Hazm's words in the introduction to his work, "Let it be known that he who reads this book of ours will find that the usefulness of this kind of work is not limited to one single discipline, but includes the
Qur'ân, Hadith and legal decisions concerning what is permissible and what is not, and what is obligatory and what is lawful." Ibn Hazm wrote a large and detailed commentary on Aristotle's "Posterior Analects". He supported certain Aristotlian concepts with enthusiasm and rejected others. He considered logic a useful tool and philosophy to be in harmony, or at least not in conflict, with revelation. He was regarded as the most observant, most careful in analysis, and most meticulous in detail and clarity of his position. His mastery of the Arabic language and his skillful use of poetry and prose are evident in all his work. His book "Tawq al-Hamamah" was a literary masterpiece in the art of love. He expressed profound insight about the dimensions of human relationships..$^{3,9,10}$

'Abbäs ibn Firnâs came to Qurțubah in the middle of the 9th century to teach music (then a branch of mathematical theory), then became interested in the mechanics of flight. He constructed a pair of wings made out of feathers in a wooden frame and attempted to fly, anticipating Leonard de Vince by some 600 years. He later was involved in the regularity of the facets of certain crystals and developed a formula for manufacturing artificial crystals. ${ }^{3}$

Al-Idrisi (1100-1166 A.D.) was a famous geographer born in southern Spain. He studied in Qurțubah and travelled widely, in Spain, North Africa, Anatolia, France and England. He settled in Sicily, where he was employed by King Roger II to write a systematic geography of the world. He wrote one of the greatest books of descriptive geography, which is still famous as a classic "Kitāb Nuzhat alMushtāq fì Ikhtirāq al-'äfāq"' (The pleasure of excursion of one who is eager to traverse the regions of the world). This book is usually known as "The Book Rogers". It represents a serious attempt to combine descriptive and astronomical geography. Al-Idrisi described the world systematically following the Greek division of it into seven climatic zones of equal width. Each climatic zone was mapped and the maps were highly accurate for the time in which they were compiled. He employed men who were sent to various countries to observe and record what they saw. They were skilled in drawings and their work was used in compiling the information. Al-Idrisi described the customs, peoples, the distance between major cities, the products and climate of the entire known world. He prepared a silver planisphere on which a map of the world was depicted. This was regarded as one of the wonders of the world. AlIdrisi also wrote scholarly books on medical matters. His work, "Kitab al-'Adwiyah al-Mufradah" (book of simple drugs), contains several names of used drugs, in 12 languages, which showed his linguistic capabilities., ${ }^{3,11}$

Ibn Zuhr (1113-1199 A.D.) is known in the West as Avenzoar, was a famous Seville physician who 
taught and practiced medicine in Andalusia in the 12 th century. He mastered anatomy and described in detail the inflammations, abscesses and tumors of the mediastinum and the way to distinguish them from pleurisy and pericardial abscesses. From his writings it would appear that medicine, surgery and pharmacy were considered to be distinct professional specialties. He mentioned for the first time the operation of tracheostomy which was his original contribution to surgery. One of his works "al-Taysir fil Mudāwah wal-Tadbiri" (book of therapeutics) was translated into Latin in 1280 A.D. and became a standard textbook of medicine in Europe until 1550 A.D. He opposed the superstitious remedies of astrologers as fakes. He introduced the laws of scientific observation and described the natural course of healing. His other famous book on foods and drugs was 'Fil-'Adwiyah wal-'Aghdhiyah". This was also used as a standard textbook of medicine. His third famous book "Kitāb al-Iqtisād" (book of moderation) deals with therapeutics, psychotherapy and hygiene. $\mathrm{He}$ is said to be the first physician to have described artificial feeding through the gullet and operations for renal calculus and tracheostomy. Medicine as a profession continued in his family for six generations. ${ }^{3-6}$

Ibn Rushd (1126-1198 A.D.) is known in the west as Averros. He was a famous philosopher of Andalusia, born in Qurțubah, studied the Qur'an, Hadith, Islamic law, astrology, mathematics, philosophy and medicine. He was appointed chief judge of Qurtubah, but was arrested because of his strong views in philosophy and religion. However, he was soon released and later appointed as a judge in Seville. He earned a great reputation as an ardent Aristotlian and had written commentaries on Aristotle which gave him the popular title "the commentator". His clear penetrating mind enabled him to present Aristotlian thoughts in a comprehensive, clear way. He added his own distinctly Islamic philosophic ideology to these thoughts. This work had a strong and positive influence on the development of European philosophy. His teachings and impact on Western Christian philosophers of the Middle Ages is called Averroism. Ibn Rushd stated that the aim of philosophy in its quest for truth is to establish the true inner meaning of religious beliefs and conviction. The inner meaning must not be divulged to the masses, who must accept the plain, external meaning of scriptures contained in stories, similies and metaphors. The unity of the outlook in ibn Rushd's religious, philosophical writings and his commentary on "The Republic" by Plato gives his political philosophy a distinctly Islamic character and tone and thereby added to his significance as a religious philosopher. His work in its Latin translation, had a lasting effect on the development of European philosophy. His most important medical work "Kitâb al-Kulliyyăt fil-Tíbb" was an encyclopedia of medicine. It dealt with anatomy, physiology, pathology, hygiene and therapeutics. He was the first to discover an immunity against smallpox. Ibn Rushd also served as a personal physician to two Caliphs of Andalusia..$^{3,12,13}$

Ibn al-'Arabī (1165-1240 A.D.) was a famous Sũfī Muslim philosopher of Spain. He incorporated many fragmented and nonsystematic mystic doctrines into a system and gave an explicit theoretical formulation. His famous work "al-Futūhāa al-Makkiyyah" described the esoteric science in Islam. He was a literary master who wrote "Turjumān al-Ashwâq", a collection of love poems upon which he himself composed a mystical commentary. His other work "Fusūs al-Hakim" was regarded as a masterpiece of mystic thoughts in Sufism. ${ }^{14}$

Ibn al-Bitâr was an Andalusian botanist of the 13 th century. He visited Africa, India and Europe to learn about plants and animals. He published three books on the medicinal plants, minerals, metals and animals. His famous book on Materia Medica is called "Collection of Simple Drugs and Foods". It is an alphabetically arranged compendium of medicinal plants. He also wrote Arabic, Roman and Berber names of the plants and gave information about the preparation of the drugs and its administration. Muslims produced the first pharmacopoeia and established the first apothecary shop. His book "al-'Adwiyah al-Mufradāh" was translated into Latin and printed in 26 editions during and after the 15 th century and used in the formation of the first London pharmacopoeia issued by the College of Physicians during the reign of King James $10^{3,6,12}$

Ibn al-Khatib was another great Andalusian physician who did extensive work on the theory of contagion. He discovered the fact that if an individual was in contact with infecion, he gets the disease, whereas he who was not in contact remains free. He also wrote about transmitting the disease through garments, vessels and earrings, etc. ${ }^{3}$

Ibn Khalduin (1332-1406 A.D.) was one of the greatest social scientists of the world. He was not born in Spain, but his ancestors and family were from Seville, Spain. He spent a major part of his life in Spain. He was the first historian who sought to develop and explicate the general laws which governed the rise and decline of civilization. He was a philosopher, historian and an outstanding social scientist. He wrote extensively on human society in general and Islamic society in particular. He constantly referred to other cultures for comparative purposes. His study of the nature of society and social changes was described in a new science called " 'Ilm al-'Umrän" (science of culture/civilization), which described human society and social transformation. He gave a sophisticated analysis of how human societies evolved from nomadism to urban 
centers and how and why these urban centers decayed and finally succumbed to less developed invaders. Anyone interested in the problems of the rise and fall of civilization, the decay of cities and the complex relationship between technologically advanced and traditional systems, should read ibn Khaldün's famous work "al-Muqaddimah" (The Introduction). This is, in fact, a philosophy of history, providing criteria necessary for distinguishing historical truth from error. His work was regarded as undoubtedly the greatest work of its kind that has ever been created by any mind in any time or place. As a theorist on history, he had no equal in any age or country. ${ }^{3-15}$

Muslim Spain, like Damascus in Syria, and other major Muslim cities of the Middle Ages, was the center of scientific and medical knowledge for the world. This was the time when the position of medicine was dismal. Medical teaching was virtually nonexistent. Europe's mental inertia began to come to an end in the 12th and 13th centuries when they became aware of the wealth of knowledge in the Muslim world. Thus the period of translation from Arabic to Latin began and European scholars journeyed to Spain to learn and translate Arabic manuscripts and returned to their native land to pursue their various fields. Thus the Muslim scientific and medical work was studied in Europe and proceeded to exert a powerful and lasting influence on the Western intellectual movement. ${ }^{7}$ Towards the end of the 12th century, a decline in Islamic medicine began to take place. Although its literary output did not diminish, it was mainly restricted to commentaries or reproduction of the famous works of the past. The decline and the eventual fall of the great civilization saw its greatest tragedy in the destruction of vast stores of knowledge accumulated through centuries by hundreds of scholars. Of the literally millions of books in the Muslim libraries, only about 250,000 volumes were saved in Eastern and Western libraries, and the rest were destroyed by the conquering Christian lords and with them, the achievements of a great many scholars and scientists were forever lost.

After the fall of "Ghirnātah" (Granada) in 1492 A.D., the Muslim states ceased to exist and many of the original Muslim elite left Spain and migrated to Morocco, Turkey, Egypt and Tunisia where they were received with sympathy and understanding. The Muslim masses were left in Spain uncared for under the Christian rule. Arabic was removed from the administration, schools attached to the mosques were barred from teaching academic and secular subjects e.g. science, mathematics, and history books were rewritten so that the future generations would not know of their glorious past. Islamic law was abolished from the land. Christian converts to Islam were persuaded to reconvert to Christianity. Within a hundred years Muslim masses gradually fell out of the grips of Muslim leadership. Most of the remaining Muslims were forced to change their religion, leave the country or they were simply executed. ${ }^{16}$ Within three centuries, hundreds of thousands of Muslims had died and three million people were driven to exile. The once brilliant Muslim universities deteriorated and thus ended the great Muslim civilization in Spain.

One wonders about the possible shape of the world today if the Muslims could have continued their reign of Spain and Muslim scientists and scholars could have continued with research and improving the sciences and technology. Maybe the world would have given more respect and recognition of Islamic contributions to the sciences and civilization. Perhaps the coming generation of Muslims will learn from history and rekindle that light again and follow in the footsteps of their ancestors.

\section{References}

1. Abercrombie TJ: When the Moors Ruled Spain. National Geographic, July, 1988, pp 86-119.

2. Gould J: Cordoba. New York Times, 1989, 5th May.

3. Lunde P: Science in al-Andalus. Published in "Science: the Islamic Legacy". Aramco, Washington, D.C. 1988, pp 21-6.

4. Bammate H: Muslim Contributions to Civilization. Crescent Publications, Maryland 1962, p 1.

5. Azmi AA: Contribution of Muslim Physicians in the Middle Ages. Hamdard, 1988, No. 1-2, pp 126-132.

6. Ashoor AZ: Muslim Medical Scholars and Their Work. Islamic World Med J 1984; 1:49-50.

7. Hayek S: How al-Zahrawi Reached the Occident. Islamic World Med J 1984; 2: 49-52.

8. Hamarneh SK: Vistas of Arabic Healing Arts in Theory and Practice, Hamdard 1989;32:3-54.

9. Chejne AG: Ibn Hazm. Kazi Publications, Chicago, Ill. 1982.

10. Encyclopedia Brittanica, 1983, Vol. 9, p 147.

11. Encyclopedia Brittanica, 1983, Vol. 9, pp 198-9.

12. Khan HR: Contributions of Muslims to Medicine and Science: up to the middle of thirteenth century JIMA 1982;14:111-4.

13. Encyclopedia Brittanica, 1983, Vol. 2, pp 538-40.

14. Encyclopedia Brittanica, 1983, Vol. 9, p 143.

15. Encyclopedia Brittanica, 1983, Vol. 9, pp 147-8.

16. Shetty R: How to Exterminate Muslims in India, Indo-American Journal of Human Rights, Published by Committee for the Defense of Human Rights in India P.O. Box 1444 Fairfax, VA 22030, March, 1989, pp 4-6. 